\title{
EVALUATION OF A GROUP OF EPILEPSY PATIENTS IN TERMS OF SLEEP QUALITY, FATIGUE AND DEPRESSION
}

\author{
Eskut Neslihan, ${ }^{1}$ Tamer Pınar, ${ }^{1}$ Delibas Hakan Dursun, ${ }^{2}$ Erdogan Esin ${ }^{2}$ \\ ${ }^{1}$ University of Health Sciences, Izmir Bozyaka Training and Research Hospital, \\ Department of Neurology, Izmir, Turkey \\ ${ }^{2}$ University of Health Sciences, Izmir Bozyaka Training and Research Hospital, \\ Department of Psychiatry, Izmir, Turkey
}

Primljen/Received 05. 07. 2020. god.

Abstract: Introduction: The aim of this study is to investigate the relationship between clinical features, sleep quality, fatigue and mental symptoms in epileptic patients.

Material and Methods: This cross-sectional study was conducted at epilepsy outpatient clinic of Bozyaka Training and Research Hospital. 81 patients who were followed up for the diagnosis of epilepsy were included in the study. The patients were administered a sociodemographic data form, Pittsburgh Sleep Quality Index, Beck Depression Inventory, Fatigue Severity Scale.

Results: The median age of the patients included in the study was $37.42(51.9 \%)$ were women and 39 $(48.1 \%)$ were men with an education period of 8 years. There was no previous family history of psychiatric illness. Seizure control was achieved in $34(42 \%)$ patients. $53(65.4 \%)$ patients were observed for focal type, $28(34.6 \%)$ patients were for generalized type seizures. The median duration of epilepsy was 13 years. The median Beck Depression Inventory score of the patients was 13 , and the number of patients with a Beck Depression Inventory score higher than 19 was 25 $(30.9 \%)$. There was mild tiredness in $47(58 \%)$ and chronic fatigue in $16(19.8 \%)$ patients. The median of Pittsburgh Sleep Quality Index total score was 4 and $18.5 \%$ (15) had poor sleep quality. Chronic fatigue was higher in epilepsy patients without seizure control compared to those with seizure control $(p=0.001)$.

Conclusion: The rate of patients with moderate and severe depression is high in our study. This indicates the significance of evaluating the diagnosis of depression in epilepsy patients. In the follow-up of these patients, it is crucial to investigate the causes of fatigue and depression carefully. Especially psychiatric expert
Prihvaćen/Accepted 28. 09. 2020. god.

opinion and multidisciplinary follow-up should be carried out without ignoring the presence of depression.

Keywords: Epilepsy, sleep quality, fatigue, depression.

\section{INTRODUCTION}

Epilepsy is a disease characterized by epileptic seizures causing neurological, cognitive, social and psychological results (1). According to World Health Organization data, epilepsy constitutes a significant part of the burden of disease in the world and affects approximately 50 million people (2). It is also known that it brings about many general medical diseases, psychiatric disorders and psychosocial problems (3). Today, the main goal of the treatment is to provide seizure control, as well as to add approaches to treatment modality to improve quality of life $(4,5)$.

Depression is more common in epileptic patients than in the general population (6). There is a mutual interaction between the disease and depression (7). Apart from ensuring seizure control in epilepsy management, it has been reported that reviewing and treating additional psychiatric diagnoses will improve the quality of life (3). On the other hand, factors such as presence of life time epilepsy, families with insufficient knowledge of the disease, and persistent social stigma lead to high levels of anxiety, depression symptoms, and a decrease in self-esteem (8-11). Fatigue and sleep problems are among the common symptoms of depression. It has been suggested that epileptic patients may experience significant deterioration in their quality of life and in cases where depression is accompanied by fatigue and sleep problems, when the intervention is not properly managed, the epileptic manifestation may worsen and drug compliance may deteriorate (12). 
Fatigue is a symptom that reduces the individual's quality of life, affects mood, and can be seen in some psychiatric and medical illnesses including epilepsy, cancer, inflammatory, endocrinological and rheumatological diseases $(13,14)$. It can be described as the feeling of tiredness and exhaustion of physical energy, independent of unhappiness or weakness (15). Studies investigating the relationship between epilepsy and fatigue have been reported to be closely associated with depression and sleep problems $(16,17)$. It was emphasized that high fatigue rates detected in epileptic patients may be related to the presence of depression, socioeconomic and cultural factors rather than seizure related factors and its frequency $(16,18)$.

In the study of Ettinger et al., the fatigue rate in the presence of depression in epileptic patients was $44 \%$, while Soyuer et al. reported this rate to be as $42.4 \%$ in epileptic patients without depression. In another study conducted in our country, fatigue rate in patients with epilepsy is $52.82 \%$. In this study, the relationship between depression, fatigue and poor quality of life was emphasized $(17,19,20)$.

Epilepsy and sleep have important effects on each other (21). In fact, the complex relationship between epilepsy and sleep has been initially noted by Aristotle and Hippocrates. In the late $1800 \mathrm{~s}$, it has been reported that approximately $1 / 5$ of epileptic seizures occurred during sleep (22). In the study of Ilhan Alp et al., $24.8 \%$ of the patients undergoing video EEG monitoring had seizures during sleep only and $55.7 \%$ of them had both in sleep and wakefulness (23). While sleep deprivation affects the frequency of epileptic seizures and the development of interictal epileptiform discharges, epileptic seizures also change the microstructural structure of the sleep (24). It has been reported that sleep disorders are more common in epileptic patients than the healthy controls (25). The relationship between epilepsy and sleep disorders is complicated. While sleep deprivation may worsen seizures, some seizures may occur during the sleep (26). Inadequate sleep and poor sleep quality can impair seizure control, and seizures themselves can cause sleep problems. In this way, a mutual vicious circle can occur. In addition, some drugs used in the treatment of epilepsy have adverse effects on sleep (27). In the light of all information, clinicians have been suggested to be sensitive to sleep problems in epileptic patients (26).

Sudden occurrence of seizures in epileptic patients and the inability to control one's own body can decrease self-confidence and leads to embarrassment. This dilemma, defined as "learned helplessness" by Abramson and Hermann, results in problems in one's professional and social relations, and depression occurs as an inevitable conclusion $(28,29)$. Thus, the role of fatigue, sleep problems and depression that can be seen in epileptic patients are crucial in the treatment.

The aim of this study is to investigate the relationship between clinical features, sleep quality, fatigue and mental symptoms in epileptic patients. The study also aims to investigate the effects of seizure control and some seizure related factors including seizure type and frequency, disease duration on depression, sleep and fatigue.

\section{MATERIAL AND METHODS}

This cross-sectional study was conducted in an epilepsy outpatient clinic of a training and research hospital. Approval was obtained from the ethics committee of the hospital for the research in accordance with the Helsinki Declaration. The study included 81 patients who were followed up with the diagnosis of epilepsy (focal or generalized) based on the criteria of 'International League Against Epilepsy'. The patients were administered a sociodemographic data form, Pittsburgh Sleep Quality Index (PSQI), Beck Depression Inventory (BDI), Fatigue Severity Scale (FSS). Informed written consent of the cases was obtained for their participation in the study. The presence of other chronic neurological diseases except epilepsy, mental retardation, psychotic disorder, substance use disorder, known sleep disorder/sleep disease, hypnotic or antidepressant drug use were determined as exclusion criteria.

Sociodemographic data form: This form prepared by the researchers, included the records of the patients' sociodemographic and disease information.

Pittsburgh Sleep Quality Index (PSQI): It is a sequential likert type self-report scale consisting of 24 questions in total (30). It provides information about the last one month of sleep quality and the type and severity of sleep disturbance. The total PSQI score ranges from 0-21. The sleep quality of those with a total score of 5 or less is considered to be "good". The Turkish validity and reliability study of the scale was conducted (31).

Beck Depression Inventory (BDI): It is a self-report scale developed by Beck in 1961 (32). The scale consists of 21 items, and each question is scored as 0 , $1,2,3$, and scores ranging from $0-63$ in total are obtained. Results are evaluated as 0-9 none/minimal depression, 10-18 mild depression, 19-29 moderate depression, 30-63 severe depression. Validity and reliability study has been conducted for Turkish society (33).

Fatigue Severity Scale (FSS): It is a self-report scale consisting of 9 items in total (34). The total score is calculated according to the average of these 9 items. Pathological fatigue cut-off value is accepted as 4 po- 
ints or above. Turkish validity and reliability study was carried out by Armutlu et al. (35).

\section{Statistical Analysis}

In this study, Statistical Package for Social Sciences (SPSS) for Windows v. 21.0 package program was used. Percentage distributions, median and extreme values of the research data are given. Chi-square test was used to investigate the difference between groups with and without seizure control, and Mann-Whitney $\mathrm{U}$ test was used to compare continuous variables. The relationship between the various clinical features of epilepsy and dependent variables in the study was examined with the spearman correlation test. Variables were examined in the $95 \%$ confidence interval and $\mathrm{p}<$ 0.05 was considered significant.

\section{RESULTS}

A total of 81 patients, $42(51.9 \%)$ women, 39 $(48.1 \%)$ men, were included in the study. The median age of the patients was 37 (17-67), their education period was $8(0-17)$ years. In terms of marital status, 32 (39.5\%) people were single. In the sample, 25 (30.9\%) people were housewives and $28(34.6 \%)$ people were working $(n=28,34.6 \%)$. The sociodemographic data of the patients are presented in Table 1. 53 patients (65.4\%) were observed with focal type and 28 (34.6\%) with generalized type seizure. Median epilepsy disease duration was 13 (1-54) years. Seizure control was achieved in $34(42 \%)$ patients for at least 1 year. The median BDI score of all patients was $13(0-47)$ and the number of patients with a BDI score higher than 19 was $25(30.8 \%) .47(58 \%)$ patients had mild and 16 $(19.8 \%)$ had chronic fatigue. The median of PSQI score of the sample was $4(0-15)$ and the sleep quality of $28(34.6 \%)$ was worse. There was no significant difference between the genders in terms of scale scores used in the study. Comparison of the scores of scales used in the study by gender is presented in Table 2 .

Table 1. Demographic and clinical features of patients with epilepsy

\begin{tabular}{|l|cc|}
\hline $\begin{array}{l}\text { Sex n (\%) } \\
\text { Female }\end{array}$ & 42 & $(51.9 \%)$ \\
Male & 39 & $(48.1 \%)$ \\
\hline Age (years) median (min-max) & 37 & {$[17-67]$} \\
\hline $\begin{array}{l}\text { Education (years) } \\
\text { median (min-max) }\end{array}$ & 8 & {$[0-17]$} \\
\hline $\begin{array}{l}\text { Marital status n (\%) } \\
\text { Single } \\
\text { Married }\end{array}$ & 32 & $(39.5 \%)$ \\
Widow/Divorced & 46 & $(56.8 \%)$ \\
\hline Job n (\%) & 3 & $(3.7 \%)$ \\
\hline $\begin{array}{l}\text { Unemployed } \\
\text { Housewife }\end{array}$ & 11 & $(13.6 \%)$ \\
$\begin{array}{l}\text { Student } \\
\text { Active worker }\end{array}$ & 25 & $(30.9 \%)$ \\
Retired & 5 & $(6.2 \%)$ \\
\hline $\begin{array}{l}\text { Seizure type n (\%) } \\
\text { Focal }\end{array}$ & 28 & $(34.6 \%)$ \\
Generalized & 12 & $(14.8 \%)$ \\
\hline $\begin{array}{l}\text { Duration of epilepsy (years) } \\
\text { median [min-max] }\end{array}$ & 53 & $(65.4 \%)$ \\
\hline
\end{tabular}

Table 2. Evaluation of the distribution of the BDI, FSS, PSQI scores of the sample and comparison of the scores by gender in patients with epilepsy

\begin{tabular}{|c|c|c|c|c|}
\hline & $\begin{array}{l}\text { Female } \\
(n=42)\end{array}$ & $\begin{array}{c}\text { Male } \\
(\mathrm{n}=39)\end{array}$ & $\begin{array}{l}\text { Total } \\
(\mathrm{n}=81)\end{array}$ & $\mathbf{p}$ \\
\hline $\begin{array}{l}\text { Total score of BDI } \\
\text { median [min-max] }\end{array}$ & $14.5[0-47]$ & $11[1-34]$ & $13[0-47]$ & 0.246 \\
\hline $\begin{array}{c}\text { Score ranges of BDI } \\
0-9 \text { score } \\
10-18 \text { score } \\
19 \text { ve more }\end{array}$ & $\begin{array}{l}12(28.6 \%) \\
16(38.1 \%) \\
14(33.3 \%)\end{array}$ & $\begin{array}{l}16(41.0 \%) \\
12(30.8 \%) \\
11(28.2 \%)\end{array}$ & $\begin{array}{l}28(34.6 \%) \\
28(34.6 \%) \\
25(30.9 \%)\end{array}$ & 0.331 \\
\hline $\begin{array}{c}\text { FSS n }(\mathbf{\%}) \\
\text { No tiredness } \\
\text { Mild } \\
\text { Chronic }\end{array}$ & $\begin{array}{l}8(19.0 \%) \\
22(52.4 \%) \\
12(28.6 \%)\end{array}$ & $\begin{array}{c}10(25.6 \%) \\
25(64.1 \%) \\
4(10.3 \%)\end{array}$ & $\begin{array}{c}18(22.2 \%) \\
47(58 \%) \\
16(19.8 \%)\end{array}$ & 0.086 \\
\hline $\begin{array}{l}\text { Total score of PSQI } \\
\text { median [min-max] }\end{array}$ & 4 [0-13] & $4[1-15]$ & 4 [0-15] & 0.277 \\
\hline $\begin{array}{l}\text { Sleep Quality n (\%) } \\
\text { Good } \\
\text { Poor }\end{array}$ & $\begin{array}{l}24(57.1 \%) \\
18(42.9 \%)\end{array}$ & $\begin{array}{l}29(74.4 \%) \\
10(26.6 \%)\end{array}$ & $\begin{array}{l}53(65.4 \%) \\
28(34.6 \%)\end{array}$ & 0.081 \\
\hline
\end{tabular}


Table 3. The relationship of clinical features of epilepsy and BDI, FSS, PSQI scores

\begin{tabular}{|c|c|c|c|c|c|c|}
\hline & $\begin{array}{l}\text { BDI score } \\
\text { median } \\
{[\text { min-max }]}\end{array}$ & $\mathbf{p}$ & $\begin{array}{l}\text { PSQI score } \\
\text { median } \\
{[\text { min-max }]}\end{array}$ & $\mathbf{p}$ & $\begin{array}{l}\text { FSS score } \\
\text { median } \\
{[\text { min-max }]}\end{array}$ & $\mathbf{p}$ \\
\hline $\begin{array}{l}\text { Seizure frequency } \\
\text { Controlled }(n=34) \\
\text { Once a month or less }(n=24) \\
\text { More than once a month }(n=23)\end{array}$ & $\begin{array}{l}10[1-36] \\
14[0-37] \\
16[1-47]\end{array}$ & 0.224 & $\begin{array}{l}4[1-15] \\
4[0-11] \\
4[1-13]\end{array}$ & 0.556 & $\begin{array}{c}4,1[1.3-7] \\
5[1.1-6.7] \\
4.3[1.3-6.4]\end{array}$ & 0.208 \\
\hline $\begin{array}{l}\text { Seizure Type } \\
\text { Focal seizure }(\mathrm{n}=53) \\
\text { Generalized seizure }(\mathrm{n}=28)\end{array}$ & $\begin{array}{l}11[1-47] \\
15[0-37]\end{array}$ & 0.195 & $\begin{array}{l}4[0-13] \\
4[1-15]\end{array}$ & 0,319 & $\begin{array}{c}4[1.1-1.7] \\
4,8[1.7-6.8]\end{array}$ & 0.106 \\
\hline Duration of epilepsy & $\mathrm{r}=0.047$ & $0.68^{*}$ & $\mathrm{r}=-0.112$ & $0.318^{*}$ & $\mathrm{r}=-0.092$ & 0.412 \\
\hline
\end{tabular}

Spearman correlation analysis, $r=$ correlation coefficent.

Table 4. Comparison of patients with epilepsy according to seizure control status in terms of BDI, FSS, PSQI scores

\begin{tabular}{|c|c|c|c|c|}
\hline & \multicolumn{2}{|c|}{ Seizure control status } & \multirow[b]{2}{*}{$\mathbf{Z} / \mathbf{d f}$} & \multirow[b]{2}{*}{$\mathbf{p}$} \\
\hline & $\begin{array}{c}\text { Controlled } \\
(\mathrm{n}=\mathbf{3 4}, \mathbf{4 2} \%)\end{array}$ & $\begin{array}{l}\text { Uncontrolled } \\
(\mathrm{n}=\mathbf{4 7}, \mathbf{5 8 \%} \%)\end{array}$ & & \\
\hline BDI (mean \pm SD) & $12.79 \pm 9.01$ & $16.45 \pm 10.67$ & -1.628 & 0.103 \\
\hline $\begin{array}{l}\text { Presense of depression } n(\%) \\
\text { No } \\
\text { Yes }\end{array}$ & $\begin{array}{c}25(73.5 \%) \\
9(26.5 \%)\end{array}$ & $\begin{array}{l}31(66 \%) \\
16(34 \%)\end{array}$ & 1 & 0.467 \\
\hline Total score of PQSI $($ mean \pm SD) & $4.79 \pm 2.90$ & $4.38 \pm 2.86$ & -0.941 & 0.346 \\
\hline $\begin{array}{l}\text { Sleep quality n (\%) } \\
\text { Good } \\
\text { Poor }\end{array}$ & $\begin{array}{l}22(64.7 \%) \\
12(35.3 \%)\end{array}$ & $\begin{array}{l}31(66 \%) \\
16(34 \%)\end{array}$ & 1 & 0.907 \\
\hline FSS score (mean \pm SD) & $4.07 \pm 1.82$ & $4.50 \pm 1.46$ & -1.034 & 0.301 \\
\hline $\begin{array}{l}\text { Presense of fatigue n (\%) } \\
\text { No } \\
\text { Yes }\end{array}$ & $\begin{array}{l}14(41.2 \%) \\
20(58.8 \%)\end{array}$ & $\begin{array}{c}4(8.5 \%) \\
43(91.5 \%)\end{array}$ & 1 & 0.001 \\
\hline
\end{tabular}

When the relationship between epilepsy clinical variables (seizure frequency, seizure type, duration of disease), BDI, PSQI and FSS scores were investigated, no statistically significant relationship was found between the variables (Table 3 ). There was no significant difference in terms of BDI score, presence of depression, total score of PSQI, sleep quality, fatigue score among epilepsy patients with and without seizure control. Chronic fatigue rate was higher in the group without seizure control $(p=0.001)$. Comparison of epileptic patients in terms of depression, sleep quality and fatigue scale scores according to the presence of seizure control is reflected in Table 4.

\section{DISCUSSION}

As a result of our research, no relation was found between epileptic seizure type, frequency of seizure and disease duration, and depression, sleep and fati- gue. It was figured out that patients without seizure control had a higher rate of chronic fatigue.

Depressive disorders are among the most common psychiatric diseases in the general population, and rates ranging from $13-35 \%$ have been reported due to the differing evaluation methods used in research (36-39). In our study, moderate and severe depression were detected in $31 \%(n=25)$ of epilepsy patients. The rate was consistent with the research results reported in the literature $(3,36,39)$. This high rate of incidence compared to the general population has been associated with bilateral interaction between epilepsy and psychiatric diseases. It has been thought that hyperactive hypothalomo-pituitary axes, limbic structures and dysfunctions, epileptic focus itself, antiepileptic drugs and social problems brought by the disease may contribute to comorbidity $(19,40)$. However, depression is often not recognized and treated as a comorbid disease. It has been 
suggested that depression should be considered in the follow-up of the epileptic patients (6).

Studies have highlighted the relationship between seizure-related factors such as disease duration, frequency of seizures, and seizure types in epileptic individuals with depression. In our study, although 16 of 25 patients with moderate and severe depression in the sample were in the group of patients without seizure control, no significant difference was found between the groups with and without seizure control in terms of BDI scores. A study reporting the frequency of seizures was ineffective on depression symptom levels supported this result (41). In the compiled study made by Scott AJ et al., the frequency of depression was higher than the general population regardless of the rate of seizure control and drug-resistant patients (39). Research suggests that the rate of psychiatric comorbidity is higher in patients without seizure control or drug-resistant cases, but our results do not support these findings (42, 43). This result may be due to the characteristics of the selected sample and the evaluation of depression based on the self-report scale. We believe that follow-up studies in epileptic patients, in which depression comorbidity or development is evaluated in larger samples by structured interview, will be beneficial.

Fatigue is a complaint far from epilepsy symptomatology; although it has not been questioned in clinical practice, it has been reported to be 4 times higher than the general population in this patient group (44). In our sample, not only the fatigue rates but also the chronic fatigue rate of the patients without seizure control were high. It has been reported that chronic fatigue has a negative effect on quality of life of the epileptic patients, where seizure control cannot be achieved (20). For this reason, clinicians are advised to be careful and to question fatigue, especially in cases without seizure control.

When the electrophysiological effects of sleep in epilepsy were investigated, it was shown that ictal and interictal epileptic discharges mostly appeared in NREM sleep, while they were suppressed in REM sleep (22). In other words, while REM sleep shows low activation in the occurrence of seizures, NREM sleep plays a trigger role by showing high activation (45). Impaired sleep quality has been reported to be $16-24.5 \%$ in studies with PSQI used to evaluate subjective sleep quality in epileptic patients $(46,47)$. In a similar study by Çillerler et al, they found poor sleep quality in $42.7 \%$ of epileptic patients using PSQI (48). Likewise, in our study, $34.6 \%$ of patients had poor sle- ep quality. Although poor sleep quality rate was higher in patients without seizure control, we could not find a statistically significant difference in PSQI scores between the two groups compared to patients without seizures. In the literature, there are studies reporting an increase in the frequency of seizures and a deterioration in sleep quality, there are also studies similar to ours that draw attention to the poor quality of sleep in epilepsy patients and do not find a relationship between seizure frequency and sleep quality $(17,46,48,49)$.

In addition to the limitations inherent in cross-sectional research, our study is among the limitations of the absence of polysomnographic examination on the cases, and no psychiatric interview structured for the diagnosis and types of depression. Despite these limitations, we think that our results will contribute to the literature in order to attract the attention of clinicians to psychiatric comorbidities in epilepsy.

\section{CONCLUSION}

Raising awareness of psychiatric symptoms in epileptic patients is essential in treatment management. It should be borne in mind that the study of fatigue, sleep disturbance and depression may affect each other and can be common in patients with epilepsy. In the presence of psychiatric comorbidities, especially depression, multidisciplinary approach and joint monitoring are essential.

Acknowledgements: The preliminary data of this study were presented as a verbal presentation in the 4th Psychiatry Submit and 11th Anxiety Congress (14-17 March 2019/Antalya, Turkey).
Abbreviations
BDI - Beck Depression Inventory
FSS - Fatigue Severity Scale
NREM - Non-Rapid Eye Movement
PSQI - Pittsburgh Sleep Quality Index
REM - Rapid Eye Movement

Conflict of Interests: The authors declare that there are no conflicts of interest related to this article.

Funding: None

\section{Licensing}

This work is licensed under a Creative Commons Attribution 4.0 International (CC BY 4.0) License. 


\title{
Sažetak
}

\section{EVALUACIJA GRUPE PACIJENATA OBOLELIH OD EPILEPSIJE U POGLEDU KVALITETA SNA, UMORA I DEPRESIJE}

\author{
Eskut Neslihan, ${ }^{1}$ Tamer Pınar, ${ }^{1}$ Delibas Hakan Dursun, ${ }^{2}$ Erdogan Esin ${ }^{2}$ \\ ${ }^{1}$ University of Health Science, Izmir Bozyaka Training and Research Hospital, \\ Department of Neurology, Izmir, Turkey \\ ${ }^{2}$ University of Health Science, Izmir Bozyaka Training and Research Hospital, \\ Department of Psychiatry, Izmir, Turkey
}

Uvod: Cilj ove studije je da ispita vezu između kliničkih karakteristika, kvaliteta sna, umora i mentalnih simptoma kod pacijenata obolelih od epilepsije.

Materijal i Metode: Ova studija preseka je sprovedena $u$ ambulanti za epilepsiju Bozyaka Training and Research Hospital. U studiju je uključen 81 pacijent. Pacijenti su popunjavali obrasce sa odgovarajućim sociodemografskim podacima, Pittsburgh Sleep Quality Index, Beck Depression Inventory, Fatigue Severity Scale.

Rezultati: Prosečna starost pacijenata uključenih u studiju bila je 37 godina. Od ukupnog broja ispitanika, $42(51,9 \%)$ bile su žene, a 39 (48,1\%) muškarci. Nije bilo pozitivne porodične anamneze u smislu psihijatrijskih bolesti. Kontrola napada postignuta je kod 34 $(42 \%)$ pacijenta. $53(65,4 \%)$ pacijenta su praćena zbog fokalnog tipa, a 28 (34,6\%) zbog generalizovanog tipa napada. Prosečna dužina trajanja bolesti bila je 13 godina. Prosečan Beck Depression Inventory skor pacije-

\section{REFERENCES}

1. Fisher RS, Acevedo C, Arzimanoglou A, Bogacz A, Cross JH, Elger CE, et al. ILAE official report: a practical clinical definition of epilepsy. Epilepsia. 2014; 55(4): 475-82.

2. https://www.who.int/news-room/fact-sheets/detail/epilepsy.

3. Demir AB, Uslu PU, Atasayar G, Kilincel O, Akkaya C, Bora I. Epilepsi hastalarinda yasam kalitesinin degerlendirilmesi ve psikiyatrik tanilarinin gozden gecirilmesi. Epilepsi. 2018; 24(1): 21-6.

4. Salgado PC, Souza EA. Quality of life in epilepsy and perception of seizure control. Arg Neuropsiquiatr. 2001; 59(3-A): $537-40$.

5. Birbeck GL, Hays RD, Cui X, Vickrey BG. Seizure reduction and quality of life improvements in people with epilepsy. Epilepsia. 2002; 43(5): 535-8.

6. Mula M. Epilepsy and depression: Clinical problems and therapeutic approaches. Epilepsi. 2012; 18(3): 1-8.

7. Kanner AM, Robot R, Masarati A. Bidirectional relations among common psychiatric and neurologic comorbidities and epilepsy: Do they have an impact on the course of the seizure disorder? Epilepsia Open. 2018; 3(2): 210-9.

8. Hung Anchor TF. Psycho-social impact of epilepsy and issues of stigma. Medical Bulletin. 2009; 14(5): 15-7.

9. Senol MG, Gun I, Togrol E, Olgun N, Saracoglu M. Epilepsi hastalarinda antiepileptik ilac tedavisine uyumu etkileyen etmenler. Duzce Tip Fakultesi Dergisi. 2009; 11(1): 21-31. nata bio je 13, a broj pacijenata sa Beck Depression Inventory skorom većim od 19 bio je 25 (30,9\%). Blagi umor bio je kod 47 (58\%) pacijenata, a hronični umor kod 16 (19,8\%). Medijana ukupnog skora Pittsburgh Sleep Quality Index bila je 4 and 18.5\% (15) je imalo loš kvalitet sna. Hronični umor je bio veći kod pacijenata sa epilepsijom bez kontrolisanih napada nego kod onih sa kontrolom napada $(\mathrm{p}=0,001)$.

Zaključak: Stopa pacijenata sa umerenom i teškom depresijom je visoka u našoj studiji. Ovo ukazuje na značaj procene dijagnoze depresije kod pacijenata sa epilepsijom. U toku praćenja ovih pacijenata od krucijalnog značaja je pažljivo ispitati uzroke umora i depresije. Naročito bi trebalo tražiti stručno mišljenje psihijatra i sprovesti multidisciplinarno praćenje bez ignorisanja prisustva depresije.

Ključne reči: epilepsija, kvalitet sna, umor, depresija.

10. Au A, Li P, Chan J, Lui C, Ng P, Kwok A, et al. Predicting the quality of life in Hong Kong Chinese adults with epilepsy. Epilepsy Behav. 2002; 3(4): 350-7.

11. Gilliam F, Hecimovic H, Sheline Y. Psychiatric comorbidity, health, and function in epilepsy. Epilepsy Behav. 2003; 4(4): 26-30.

12. Neves GS, Gomes MDM. Fatigue in patients with epilepsy and its association with depression and sleep quality. Arq Neuropsiquiatr. 2013; 71(8): 533-6.

13. Chaudhuri A, Behan PO. Fatigue in neurological disorders. Lancet. 2004; 3638(9413): 978-88.

14. Birbeck GL, Hays RD, Cui X, Vickrey BG. Seizure reduction and quality of life improvements in people with epilepsy. Epilepsia 2002; 43(5): 535-8.

15. Perrine KR. A new quality of life inventory for epilepsy patients:interim results. Epilepsia. 1993; 34(4): 28-33.

16. Kwon OY, Ahn HS, Kim HJ. Fatigue in epilepsy: A systematic review and meta-analysis. Seizure. 2017; 45: 151-9.

17. Ettinger AB, Weisbrot DM, Krupp LB, Coyle PK, Jandorf L, Devinsky O. Fatigue and depression in epilepsy. Journal of Epilepsy. 1998; 11(2): 105-9.

18. Kwon OY, Park SP. Interictal fatigue and its predictors in epilepsy patients: A case-control study. Seizure. 2016; 34: 48-53.

19. Soyuer F, Erdogan F, Senol V, Arman F. The relationship between fatigue and depression, and event-related potentials in epileptics. Epilepsy Behav. 2006; 8(3): 581-7. 
20. Erdogan F, Soyuer F, Senol V, Arman F. Epilepsi hastalarinda yorgunlugun yasam kalitesine etkisi. Epilepsi. 2006; 12(1): 21-6.

21. Malow BA. The interaction between sleep and epilepsy. Epilepsia. 2007; 48(9): 36-8.

22. Kataria L, Vaughn BV. Sleep and epilepsy. Sleep Med Clin. 2016; 11(1): 25-38.

23. Ilhan Alp S, Baklan B. Epileptik nobetlerin sirkadiyen dagilimi. International Anatolia Academic Online Journal. 2019; 5(1): 18-31.

24. Parrino L, Spaggiari MC, Boselli M, Barusi R, Terzano MG. Effects of prolonged wakefulness on Cyclic alternating pattern (CAP) during sleep recovery at different circadian phases. J. Sleep Res. 1993; 2(2): 91-5.

25. Passouant P. Historical aspects of sleep and epilepsy. Epilepsy Res Suppl. 1991; 2:19-22.

26. Staniszewska A, Maka A, Religioni U, Olejniczak D. Sleep disturbances among patients with epilepsy. Neuropsychiatr Dis Treat. 2017; 13: 1797-803.

27. Tork MA, Rashed HR, Elnabil L, Salah-Eldin N, Elkhayat $\mathrm{N}$, Abdelhady AA, et al. Sleep pattern in epilepsy patients: a polysomnographic study. Egypt J Neurol Psychiatr Neurosurg. 2020; 56(1): 1-5.

28. Abramson LY, Seligman MEP, Teasdale JD. Learned helplessness in humans: critique and reformilation. J Abnorm Psychol. 1978; 87(1): 49-74.

29. Hermann BP, Trenery MR, Collingan RC. Learned helplessness, attirubitional style and depression in epilepsy. Epilepsia. 1996; 37(7): 680-6.

30. Buysse DJ, Reynolds CF, Monk TH, Berman SR, Kupfer DJ. The pittsburgh sleep quality 2ndex: a new 2nstrument for psychiatric practice and research. Psychiatric Res. 1989; 28(2): 193-213.

31. Agargun MY, Kara H, Anlar O. Pittsburgh uyku kalitesi indeksinin gecerligi ve guvenirligi. Turk Psikiyatri Derg. 1996; 7(2): 107-15.

32. Beck AT. An inventory for measuring depression. Arch Gen Psychiatry. 1961; 4: 561-7.

33. Hisli N. Beck Depresyon Envanteri'nin Universite Ogrencileri icin Gecerligi, Guvenirligi. Psikoloji Dergisi. 1989; 7(23): 3-13.

34. Krupp LB, LaRocca NG, Muir-Nash J, Steinberg AD. The fatigue severity scale. Application to patients with multiple sclerosis and systemic lupus erythematosus. Arch Neurol. 1989; 46(10): 1121-3.

35. Armutlu K, Korkmaz NC, Keser I, Sumbuloglu V, Akbiyik DI, Guney Z, et al. The validity and reliability of the Fati- gue Severity Scale in Turkish multiple sclerosis patients. Int $\mathbf{J}$ Rehabil Res. 2007; 30(1): 81-5.

36. St Germaine-Smith C, Liu M, Quan H, Wiebe S, Jette N. Development of an epilepsy-specific risk adjustment comorbidity index. Epilepsia. 2011; 52(12): 2161-7.

37. Kim M, Kim YS, Kim DH, Yang TW, Kwon OY. Major depressive disorder in epilepsy clinics: A meta-analysis. Epilepsy Behav. 2018; 84: 56-69.

38. Fiest KM, Dykeman J, Patten SB, Wiebe S, Kaplan GG, Maxwell CJ, et al. Depression in epilepsy: a systematic review and meta-analysis. Neurology. 2013; 80(6): 590-9.

39. Scott AJ, Sharpe L, Hunt C, Gandy M. Anxiety and depressive disorders in people with epilepsy: A meta-analysis. Epilepsia. 2017; 58(6): 973-82.

40. Kanner AM. Depression and epilepsy: a bidirectional relation? Epilepsia. 2011; 52(1): 21-7.

41. Yasar H, Alay S, Kendirli T, Tekeli H, Senol MG, Turker T, Saracoglu M. Genc erkek epilepsi hastalarinda yasam ve uyku kalitesi. Epilepsi. 2014; 20(1): 17-22.

42. Gilliam F, Hecimovic H, Sheline Y. Psychiatric comorbidity, health, and function in epilepsy. Epilepsy Behav. 2003; 4(4): 26-30.

43. Kanner AM. Depression in epilepsy is much more than a reactive process. Epilepsy Curr. 2003; 3(6): 202-3.

44. Hernandez-Ronquillo L, Moien-Afshari F, Knox K, Britz J, Tellez-Zenteno JF. How to measure fatigue in epilepsy? The validation of three scales for clinical use. Epilepsy Res. 2011; 95(1-2): 119-29.

45. Shoue MN, Scordato JC, Farber PR. Sleep and arousal mechanisms in experimental epilepsy: epileptic components of NREM and antiepileptic components in REM sleep. Ment Retard Dec Disabil Res Rev. 2004; 10(2): 117-21.

46. Dede HO, Bebek N, Akarsu EO, Samanci B, Karbay M, Gurses C, et al. Relationship between sleep characteristics and sudden unexplained death risk in epilepsy.Neurologist. 2019; 24(6): 170-5.

47. Ismayilova V, Demir AU, Tezer FI. Subjective sleep disturbance in epilepsy patients at an outpatient clinic: a questionnaire-based study on prevalence. Epilepsy Res. 2015; 115: 119-25.

48. Cilliler AC, Guven B. Sleep quality and related clinical features in patients with epilepsy: a preliminary report. Epilepsy Behav. 2020; 102:106661. doi: 10.1016/j.yebeh.2019.106661. Epub 2019 Nov 23.

49. Saraswati N, Nayak C, Sinha C, Nagappa M, Thennarasu K, Taly AB. Comparing sleep profiles between patients with Juvenile myoclonic epilepsy and symptomatic partial epilepsy: sleep questionnaire-based study. Epilepsy Behav. 2017; 66: 34-8.

\author{
Correspondence to/Autor za korespondenciju \\ Neslihan Eskut, MD \\ University of Health Sciences, Izmir Bozyaka Training and Research Hospital, \\ Department of Neurology, Izmir, Turkey \\ phone: +905054432205 \\ email: nespur@hotmail.com \\ https://orcid.org/0000-0003-1882-8992
}

